\title{
Properties of Antioxidant and Anti-Inflammatory Activity and Phenolic Profiles of Şevketi Bostan (Cnicus benedictus L.) Cultivated in Aegean Region from Turkey
}

\author{
Zehra Can $^{1 *}$, Nimet Baltaş ${ }^{2}$, Şaban Keskin ${ }^{3}$, Oktay Yıldız ${ }^{4}$, Sevgi Kolaylı ${ }^{4}$ \\ ${ }^{1}$ Sebinkarahisar Technical Sciences Vocational School, Giresun University, 28400 Giresun, Turkey \\ ${ }^{2}$ Faculty of Arts and Science, Department of Chemistry, Recep Tayyip Erdogan University, 53100 Rize, Turkey \\ ${ }^{3}$ Department of Chemistry, Faculty of Arts and Science, Bilecik Seyh Edebali University, 11600 Bilecik, Turkey \\ ${ }^{4}$ Department of Chemistry, Faculty of Science, Karadeniz. Thecnical University, 61080 Trabzon, Turkey
}

\begin{tabular}{l} 
A R T I C L E I N F O \\
Research Article \\
Received 25 October 2016 \\
Accepted 19 February 2017 \\
\hline
\end{tabular}

Keywords:

Antioxidant

Cnicus benedictus L.

Milk thistle

Inhibition

Phenolic compounds

$\overline{\text { *Corresponding Author: }}$

\begin{abstract}
A B S T R A C T
The aim of this work was to evaluate the phenolic profiles and anti-inflammatory, antioxidant and gastro-protective activities of Cnicus benedictus L., a type of milk thistle cultivated in Turkey. The total phenolic content (TPC), total flavonoid content (TFC), ferric reducing antioxidant power (FRAP) and the 2,2-diphenyl-1-picryhydrazyl (DPPH) free radical scavenging activity was measured to determine antioxidant capacity. The anti-urease and anti-xanthine oxidase activities were used to determine the gastroprotective and anti-inflammatory potential of the plant extracts, respectively. The TPC was 337.40 and $635.10 \mathrm{mg}$ of gallic acid equivalents (GAE)/100 $\mathrm{g}$ and TFC was $41.05-$ $119.12 \mathrm{mg}$ of quercetin equivalents $(\mathrm{QE}) / 100 \mathrm{~g}$ in the root and leaf extracts, respectively. The root and leaf extracts of Cnicus benedictus L., were exhibited different inhibition values against both of the enzymes. The inhibition effect of the both enzymes were calculated as $\mathrm{IC}_{50}(\mathrm{mg} / \mathrm{mL})$ in terms of $50 \%$ inhibition of the enzymes. The xanthine oxidase activity of the leaf and root was 18.53 and $19.75 \mathrm{mg} / \mathrm{mL}$ and the urease activity were $2.29 \mathrm{mg} / \mathrm{mL}$ and $11.53 \mathrm{mg} / \mathrm{mL}$, respectively. Fifteen phenolic compounds were determined by high-performance liquid chromatography (HPLC-UV). Vanillic, silibinin $\mathrm{B}$, ferulic acid and rutin were found major amount of the plant. In conclusion, the plant have high potential beneficial nutraceuticals and consumption of the together with its roots and leafs will be beneficial in terms of nutrition.
\end{abstract}

\section{Introduction}

Cnicus benedictus L., commonly known as St. Benedict's thistle and locally known as Şevketi bostan (or şevket otu), is a member of the Asteraceae family (Lucini et al., 2016). C. benedictus L., is native to Turkey, where it is widespread, as well as other Mediterranean countries, but is also cultivated in a wide range of geographical areas from South Africa to South America. In the last decade, humans have begun to cultivate the plant as a food source and additive in the west of Turkey. There have been many species of milk thistle reported, and these plants contain secondary metabolites such as glycosides, bioactive azo compounds, flavonoids, flavanolignins (silymarin) and rosmarinic acid. These metabolites are important pharmaceutical agents for the treatment of lung and colon cancers, such hepatitis (Eşiyok et al., 2004; Liu et al., 2007; Ahmed-Belkacem et al., 2010). Polyphenols are a wide family of natural substances, contains many subunits such as phenolic acids, flavonoids, procyanins, anthocyanins, tannins and lignins. They are synthesized by the Shikimate pathway in plants, and have many important physiological and non-physiological roles, specifically anti-oxidant, anti-microbial, anti-viral, antitumoral and anti-inflammatory effects. These bioactivities properties are related to the phenolic composition of the plant (Can et al., 2015). Polyphenols are reducing, scavenging, chelating, anti-bacterial, coagulant, stabilizer, surfactant and stimulant agents, and therefore, they have many uses (Hernmann, 1995; Kuppusamyet al., 2015; Can et al., 2015; Havsteen, 2002).

A mixture of silymarin comprised of flavonolignans that are present in high amounts in milk thistle, containing flavonoids including silibinin A, silibinin $\mathrm{B}$, isosilibinin $\mathrm{A}$ and isosilibinin B (Ahmed-Blekacem et al., 2010; Y1ldız et al., 2013). Previous reported that silymarin content most often ranges from 1 to $3 \%$ of dry matter, but other reported that New Zealand and Europe different silymarin contents exceed 8\% (Martin et al., 2006). 
Polyphenolic compounds are the main secondary metabolites that found in foods (Naczk and Shahidi, 2004; Shahidi and Ambigaipalan, 2015). Some of the biologically active properties and phenolic substances have been previously investigated in the consumed parts of Cnicus benedictus L. In the current study, the total phenolic content (TPC), total flavonoid content (TPF), ferric reducing antioxidant power (FRAP) and 2,2diphenyl-1-picryhydrazyl (DPPH) free radical scavenging activity were used to evaluate the antioxidant activity of Cnicus benedictus L. The inhibition of jack bean urease and bovine milk xanthine oxidase (XO) were also determined to evaluate the gastro-protective and antiinflammatory activities. Reactive oxygen species (ROS) or free radicals are produced in many physiological and nonphysiological pathways in living organisms (Salla et al., 2016; Chen et al., 2016). There are many enzymes that catalyze ROS production in different metabolic pathways, such as XO nitric oxide synthase, myeloperoxidase and aldehyde oxidase. $\mathrm{XO}$ is responsible for the oxidative damage responsible for several pathological diseases, including gout, hyperuricemia, hepatitis and aging (Mehta et al., 2014). Therefore, inhibiting this enzyme is important for the prevention of many inflammatory diseases (Sahin, 2015).Urease catalyses the degradation of urea in many physiological processes, and inhibiting urease is particularly important in the treatment of gastric diseases caused by Helicobacter pylori (Kolayli et al., 2015; Ndemangou et al., 2013).

Either natural or cultivated of Şevketi bostan (Cnicus benedictus L.) is often consumed in the Aegean region of Turkey as a vegetable and our purpose was also to evaluate its nutraceutical properties in this study. For this reason, some phenolic compounds and antioxidant, antiurease, anti-xanthine oxidase activities were determined in leaf and root parts of the plant.

\section{Materials and Methods}

\section{Chemicals}

All reagents used were of analytical grade. Gallic acid, protocatechuic acid, $p$-hydroxybenzoic acid, vanillic acid, caffeic acid, catechin, syringic acid, $p$-coumaric acid, ferulic acid, epicatechin, rutin, $t$-cinnamic acid, luteolin, silibinin A and silibinin B were obtained from SigmaAldrich Chemie GmbH (Munich, Germany) and Merck (Darmstadt, Germany).Trolox was supplied by SigmaAldrich Appli Chem (Darmstadt, Germany). FolinCiocalteu phenol reagent and 2,4,6-Tris(2-pyridyl)-striazine(TPTZ) were purchased from Fluka Chemie GmbH (Switzerland). Bovine milk XO, xanthine, jack bean urease, urea, allopurinol and thiourea were acquired from Sigma-Aldrich (St. Louis, MO, USA). Sodium acetate, ferric chloride and glacial acetic acid were obtained from Merck. Sodium nitroprusside, iron(III) chloride hexahydrate $\left(\mathrm{FeCl}_{3} \cdot 6 \mathrm{H}_{2} \mathrm{O}\right)$, iron(II) sulfate heptahydrate $\left(\mathrm{FeSO}_{4} .7 \mathrm{H}_{2} \mathrm{O}\right)$ and $\mathrm{DPPH}$ were purchased from Sigma-Aldrich.LC syringe filters (RC15, RC- membrane, $0.2 \mu \mathrm{m}$ ) were obtained from Sartorius Minisart (Darmstadt, Germany).

\section{Preparation of the Extracts}

Cnicus benedictus L., was supplied by the EGE Agricultural Research Centre of the Agricultural Ministry in Menemen, İzmir, of Turkey, in June 2015 which cultivated the plant. Both roots and leaves of the plant were dried between 35 and $40^{\circ} \mathrm{C}$ for reduce moisture content in plant. For the preparation of the leaf and root extracts $10 \mathrm{~g}$ of dried sample was placed in a flax with $100 \mathrm{~mL}$ methanol (99\%) and stirred with a shaker (Promax 2020; Heidolph, Schwabach, Germany) at room temperature for 24 hours, then sonicated for 3 hours with a ultrasonicator (ultrasonic Elma Scmidbauer $\mathrm{GmbH}$ ) Germany. The mixture was filtered with filter paper (Whatman) and concentrated in a rotary evaporator (IKAWerke, Staufen, Germany) at $40^{\circ} \mathrm{C}$. The residue was then resolved with a minimal volume of methanol and kept at $4^{\circ} \mathrm{C}$ until use.

\section{Analysis of Phenolic Compounds by HPLC}

For preparation of the samples to HPLC analysis, the residue was dissolved in $15 \mathrm{~mL}$ acidified distilled water ( $\mathrm{pH} 2$ ), and extracted three times with $15 \mathrm{~mL}$ of diethyl ether:ethyl acetate mixtures $(1: 1 \mathrm{v} / \mathrm{v})$.After extractions, the organic phases were assembling and the organic solvents were removed using a rotary evaporator. The residue was dissolved in methanol, and injected to HPLC.

Fifteen phenolic compound standards were analyzed using HPLC (Elite LaChrom; Hitachi, Tokyo, Japan). The samples were injected into the HPLC system with a reverse phase C18 column $(150 \mathrm{~mm} \times 4.6 \mathrm{~mm}, 5 \mu \mathrm{m}$; fortis). Acetonitrile, water and acetic acid were used as the mobile phase, and a programmed gradient was applied. The phase consisted of (A) $2 \%$ acetic acid in water and (B) acetonitrile: water (70:30). The sample injection volume was $20 \mu \mathrm{L}$, with a column temperature of $30^{\circ} \mathrm{C}$ and flow rate of $0.75 \mathrm{~mL} / \mathrm{min}$. The solvent program began with a linear gradient of $95 \%$ A for 3 minutes, which decreased to $80 \% \mathrm{~A}$ at 10 minutes, $60 \% \mathrm{~A}$ at 20 minutes, $20 \% \mathrm{~A}$ at 30 minutes and finally $95 \% \mathrm{~A}$ at 50 minutes (Can et al., 2015).

\section{Determination of Total Phenolic Content}

The Folin-Ciocalteau procedure was used for the determination of TPC, gallic acid was used as standard (Slinkard and Singleton, 1977). Briefly, $680 \mu \mathrm{L}$ of distilled water, $400 \mu \mathrm{L}$ of $0.5 \mathrm{~N}$ Folin-Ciocalteu reagents and $20 \mu \mathrm{L}$ of different concentrations of gallic acid were added to each of the samples, which were then vortexed. After 3 minutes, $400 \mu \mathrm{L}$ of $\mathrm{Na}_{2} \mathrm{CO}_{3}$ solution $(10 \%)$ was added and vortexed. The mixture was then incubated for 2 hours at $20^{\circ} \mathrm{C}$ with intermittent shaking. The absorbance at $760 \mathrm{~nm}$ was measured at the end of the incubation period. A standard curve was prepared from the gallic acid standards of different concentrations, and the results were expressed as mg gallic acid equivalents (GAE) per $100 \mathrm{~g}$ of the methanolic extracts. 


\section{Determination of Total Flavonoid Content}

Total flavonoids contents that present in the methanolic extracts were measured using a spectrometric assay. Firstly, $0.5 \mathrm{~mL}$ of the sample, $0.1 \mathrm{~mL}$ of $10 \%$ $\mathrm{Al}\left(\mathrm{NO}_{3}\right)_{3}$ and $0.1 \mathrm{~mL}$ of $1 \mathrm{M} \mathrm{NH}_{4} \cdot \mathrm{CH}_{3} \mathrm{COO}$ were added to experimental tube and incubated at room temperature for 40 minutes. The absorbance was then measured at 415 nm against a blank. Quercetin was used as the standard for the preparation of the calibration curve. The TFC was expressed as mg of quercetin equivalents (QE) per $100 \mathrm{~g}$ sample (Fukumoto and Mazza, 2000).

\section{Determination of Ferric Reducing Antioxidant Power (FRAP)}

The FRAP assay was conducted to determine the total antioxidant capacity of the samples. This method is based on the reduction of the $\mathrm{Fe}(\mathrm{TPTZ})^{3+}$ tripyridyltriazine complex to the blue colored Fe(TPTZ) ${ }^{2+}$ by antioxidants in the acidic medium (Benzie and Strain, 1996). The working FRAP reagent was prepared by mixing $25 \mathrm{~mL}$ of $0.3 \mathrm{M}$ acetate buffer (pH 3.6) with $2.5 \mathrm{~mL}$ of $10 \mathrm{mM}$ TPTZ in a solution with $40 \mathrm{mMHCl}$ and $2.5 \mathrm{~mL}$ of 20 $\mathrm{mM} \mathrm{FeCl} 3 \cdot 6 \mathrm{H}_{2} \mathrm{O}$. A $100 \mu \mathrm{L}$ aliquot of sample was added to $3 \mathrm{~mL}$ of the freshly prepared FRAP reagent mixture, then incubated at $37^{\circ} \mathrm{C}$ for 4 minutes. The absorbance was determined at $593 \mathrm{~nm}$ against a blank of distilled water. For preparing a calibration curve ferrous sulphate solution $\left(\mathrm{FeSO}_{4} .7 \mathrm{H}_{2} \mathrm{O}\right)$, ranging from $100-1000 \mu \mathrm{M}$, was used. The values obtained by the FRAP assay were expressed as $\mathrm{mM}$ of ferrous equivalent Fe (II) per $100 \mathrm{~g}$ weight of the sample.

\section{Free Radical-Scavenging Activity of DPPH}

The DPPH assay was performed using the method described by Molyneux (2004) to determine the radical scavenging capacity of the metholic extracts. This simple method is based on the DPPH radical scavenging ability of the antioxidants within the extracts. For each sample, $0.75 \mathrm{~mL}$ of the extracts at six different concentrations were mixed with $0.75 \mathrm{~mL}$ of $0.1 \mathrm{mM}$ of $\mathrm{DPPH}$ in methanol, and the absorbance was read at $517 \mathrm{~nm}$. The results were expressed as $\mathrm{SC}_{50}(\mathrm{mg}$ sample per $\mathrm{mL}$ ), which represented the concentration of each sample that resulted in 50\% scavenging of DPPH.

\section{Determination of Xanthine Oxidase Inhibition}

The inhibition of XO was measured spectrometrically from uric acid that released from xanthine (Hayashi et al., 1988). The reaction mixture, consisting of $0.5 \mathrm{~mL}$ of the sample extract, $0.77 \mathrm{~mL}$ of phosphate buffer $(\mathrm{pH} 7.8)$ and $0.07 \mathrm{~mL}$ of bovine milk XO, was incubated at $25^{\circ} \mathrm{C}$ for 15 minutes. Afterwards, $0.66 \mathrm{~mL}$ of substrate solution was added to the mixture, which was incubated for 15 minutes at $25^{\circ} \mathrm{C}$. The reaction was stopped by adding $0.2 \mathrm{~mL}$ of $0.5 \mathrm{~N} \mathrm{HCl}$, and the absorbance was measured at $295 \mathrm{~nm}$ using an ultraviolet/visible spectrophotometer (1601UVShimadzu, Australia).Allopurinol, (Sigma-Aldrich, St. Louis, MO) an inhibitor of XOI, was used as positive control. The assay was performed in triplicate, for calculating standard deviation. The result was expressed as $\mathrm{IC}_{50}$.

\section{Determination of Urease Inhibition}

Jack bean urease was used to calculate the urease inhibition of the extracts. The assay was based on production of ammonia, as determined using the indo phenols method, which has an absorbance of $625 \mathrm{~nm}$ (Weatherburn, 1967). The reaction mixture included 250 $\mu \mathrm{L}$ of jack bean urease, $500 \mu \mathrm{L}$ of buffer $(100 \mathrm{mM}$ urea, 0.01 $\mathrm{M} \mathrm{K}_{2} \mathrm{HPO} 4,1 \mathrm{mM}$ EDTA and 0.01 M LiCl; pH 8.2), to which $100 \mu \mathrm{L}$ of the extract was added. After incubating at room temperature for 20 minutes, $550 \mu \mathrm{L}$ of phenol reagent $(1 \% \mathrm{w} / \mathrm{v}$ phenol and $0.005 \% \mathrm{w} / \mathrm{v}$ sodium nitroprusside) and $650 \mu \mathrm{L}$ of an alkali reagent $(0.5 \% \mathrm{w} / \mathrm{v}$ $\mathrm{NaOH}$ and $0.1 \% \mathrm{v} / \mathrm{v} \mathrm{NaOCl})$ were added, and the optical density was measured at $625 \mathrm{~nm}$. Acetohydroxamic acid was used as the standard inhibitor. The $\mathrm{IC}_{50}$ of the extracts were calculated from the dose response curve, generated using different concentrations of the extracts.

\section{Statistical Analysis}

The arithmetical means and standard deviations were calculated for all data. SPSS software (version 13; SPSS Inc., Chicago, IL, USA) was used to calculate of all statistical. The differences between the leaf and root of the plant were determined by the Kruskal-Wallis test, and the correlation between two data was determined using Pearson's correlation coefficient. Significant differences were identified as $\mathrm{P}<0.05$.

\section{Results}

The total polyphenol content of the methanolic extracts was measured using the Folin-Ciocalteu method with gallic acid as the standard (Table 1). Shows the total phenolic and flavonoid contents of both extracts. The TPC ranged from 337.40 to $635.10 \mathrm{mg}$ GAE/100 $\mathrm{g}$ extract, and the TPC of the leaf extract was two-times higher than the root extract. The TFC was also higher in the leaf $119.12 \pm 2.20 \mathrm{mg} Q \mathrm{QE} / 100 \mathrm{~g}$ extract. FRAP and DPPH values were calculated using $\mathrm{FeSO}_{4} 7 \mathrm{H}_{2} \mathrm{O}$ and Trolox@ as an antioxidant standard respectively. FRAP values 1.77 to $2.08 \mathrm{mmol}^{\mathrm{FeSO}} \mathrm{SH}_{2} \mathrm{O} / 100 \mathrm{~g}$ root and leaf DPPH values 2.40 to $1.84 \mathrm{mg} / \mathrm{mL}$ root and leaf.

The specific concentration of phenolic compounds in the root and leaf extracts of Cnicus benedictus L. was measured by HPLC. The Reversed-Phase HighPerformance Liquid Chromatography (RP-HPLC) chromatograms of the standard phenolic compounds are presented in Figure 1. The quantities of each of the phenolic acids were calculated from three separate measurements and presented as the mean $\mu \mathrm{g} / \mathrm{g}$ sample (Table 2). Fifteen phenolic substances were measured, with 11 phenolics detected in the samples from both parts of the plant. Vanillic acid and silibinin B were clearly the most abundant phenolic acids in both the roots and leaves. In general, the leaves of the plants have a higher concentration of phenolic compounds, however, the root extract of $C$. benedictus L. was also found to be rich in rutin, $t$-cinnamic acid, protocatechuic acid, gallic acid, $p$ coumaric acid and $p$-OH benzoic acid (Table 2). Silibin B and vanillic acid was detected in both leaf and root high 
level of concentration. Catechin, epicatechin and silibinin A was not detected neither roots or leafs extract. Ferulic acid, the hydroxycinnamic acid derivative, was also found at high levels in leaf extract while was found a little in root extract. Luteolin as a flavonoid was detected in the leaf extract while was not detected in the root extract.

In addition to study was also investigated the antiurease and anti-xanthine oxidase activities of methanolic extracts of the plant. The results obtained in the study for the inhibition values are presented in Table 3, urease XO was found related with antioxidant capacities this Cnicus benedictus L. plant $(\mathrm{P}<0.05)$ Table 4 . The anti-xanthine oxidase activities were found to be $18.53 \pm 0.13$ in leaf and $19.75 \pm 0.13(\mathrm{mg} / \mathrm{mL})$ in root. The anti-urease activities were found to be $2.29 \pm 0.07$ was leaf $11.53 \pm 0.03$ $(\mathrm{mg} / \mathrm{mL})$ in root.

Table 1 Antioxidant activity results of Cnicus benedictus L.

\begin{tabular}{l|cccc}
\hline \multicolumn{1}{c}{ Sample } & $\begin{array}{c}\text { TPC } \\
(\mathrm{mgGAE} / 100 \mathrm{~g} \text { extract })\end{array}$ & $\begin{array}{c}\text { TFC } \\
(\mathrm{mgQE} / 100 \mathrm{~g} \text { extract })\end{array}$ & $\begin{array}{c}\text { FRAP } \\
\left(\mathrm{mmol} \mathrm{FeSO} 7 \mathrm{H}_{2} \mathrm{O} / 100 \mathrm{~g} \text { extract }\right)\end{array}$ & $\begin{array}{c}\text { DPPH SC } \\
(\mathrm{mg} / \mathrm{mL})\end{array}$ \\
\hline Leaf & $635.10 \pm 5.15^{\mathrm{a}}$ & $119.12 \pm 2.20^{\mathrm{a}}$ & $2.08 \pm 0.88^{\mathrm{a}}$ & $1.84 \pm 0.03^{\mathrm{a}}$ \\
Root & $337.40 \pm 3.64^{\mathrm{b}}$ & $41.05 \pm 1.17^{\mathrm{b}}$ & $1.77 \pm 0.05^{\mathrm{b}}$ & $2.40 \pm 0.05^{\mathrm{b}}$ \\
Trolox$\subset$ & & & & $0.004 \pm 0.01$ \\
\hline${ }^{\mathrm{a}, \mathrm{b}}$ Different letters in the same column are significantly different at the 5\% level $(\mathrm{P}<0.05)$. &
\end{tabular}

Table 2 Phenolic profiles of Cnicus benedictus L. ( $\mu \mathrm{g} / 100 \mathrm{~g})$

\begin{tabular}{l|cc}
\hline \multicolumn{1}{c|}{ Compounds } & Root $(\mu \mathrm{g} / 100 \mathrm{~g})$ & Leaf $(\mu \mathrm{g} / 100 \mathrm{~g})$ \\
\hline Gallic acid & $184.01 \pm 1.00$ & $36.03 \pm 1.01$ \\
Protocatechuic acid & $197.00 \pm 3.00$ & $37.00 \pm 2.00$ \\
$p$-OH benzoic acid & $96.02 \pm 3.00$ & $46.01 \pm 4.01$ \\
Catechin & nd & nd \\
Vanillic acid & $1768.00 \pm 184.0$ & $6391.01 \pm 20.01$ \\
Caffeic acid & $44.01 \pm 2.01$ & $46.03 \pm 10.01$ \\
Syringic acid & $175.03 \pm 2.00$ & $317.01 \pm 10.01$ \\
Epicatechin & nd & nd \\
$p$-Coumaric acid & $55.01 \pm 1.03$ & nd \\
Ferulic acid & $2.00 \pm 0.10$ & $1584.01 \pm 9.01$ \\
Rutin & $889.02 \pm 1.00$ & $486.00 \pm 3.03$ \\
$t$-Cinnamic acid & $195.01 \pm 3.02$ & $81.01 \pm 1.00$ \\
Luteolin & nd & $95.01 \pm 1.01$ \\
Silibinin A & nd & nd \\
Silibinin B & $1292.00 \pm 7.01$ & $2003.00 \pm 121.01$ \\
\hline
\end{tabular}

The results are the mean value of three separate analyses, expressed as $\mu \mathrm{g} / \mathrm{g}$ extract of the dry sample. nd, not determined.

Table 3 Inhibition concentrations ( $\mathrm{IC}_{50}, \mathrm{mg} / \mathrm{mL}$ ) of Cnicus benedictus $\mathrm{L}$. for jack bean urease and bovine milk xanthine oxidase

\begin{tabular}{l|cc}
\multicolumn{1}{c|}{ Sample } & Anti-XO activity & Anti-Urease activity Anti-urease activity \\
\hline Leaf & $18.53 \pm 0.13^{\mathrm{a}}$ & $2.29 \pm 0.07^{\mathrm{a}}$ \\
Root & $19.75 \pm 0.21^{\mathrm{a}}$ & $11.53 \pm 0.03^{\mathrm{b}}$ \\
Allopurinol $^{*}$ & $0.54 \pm 0.01$ & - \\
Acetohydroxamic acid $^{*}$ & - & $12.11 \pm 0.001$ \\
\hline${ }^{*} \mathrm{IC}_{50}$ Values are expressed as $\mu \mathrm{g} / \mathrm{mLL}^{\mathrm{a}, \mathrm{b}}$ Different letters in the same column are significantly different at the 5\% level $(\mathrm{P}<0.05)$
\end{tabular}

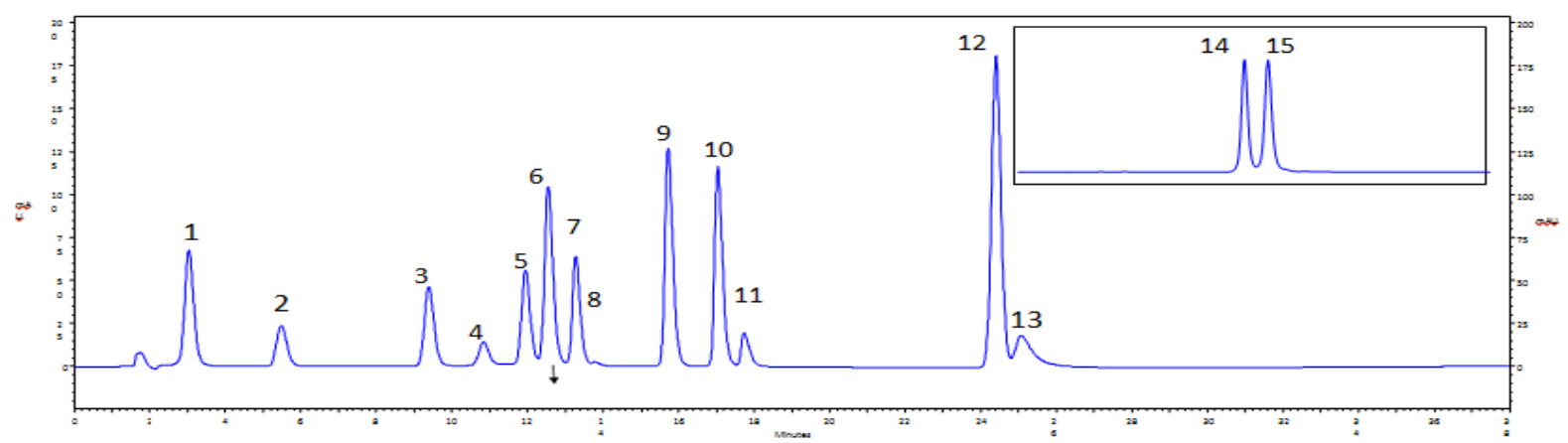

Figure 1 HPLC-UV chromatograms of phenolic standards, 1. Gallic acid, 2. Protocatechuic acid, 3. p-OH benzoic acid, 4. Catechin, 5. Vanilic acid, 6. Caffeic acid, 7. Syringic acid, 8. Epicatechin, 9. p-Cumaric acid, 10. Ferulic acid, 11. Rutin, 12. t-cinnamic acid, 13. Luteolin, 14. Silibin A, 15. Silibin B 
Table 4 Correlation table of Cnicus benedictus L.

\begin{tabular}{|c|c|c|c|c|c|}
\hline & & $\mathrm{XO}$ & Urease & FRAP & DPPH \\
\hline \multirow{5}{*}{$\mathrm{XO}$} & PearsonCorrelation & 1 & $0.975(* *)$ & -0.330 & $0.961(* *)$ \\
\hline & Sig. (2-tailed) & & 0.001 & 0.523 & 0.002 \\
\hline & Sum of Squaresand Cross-products & 2.466 & 17.319 & -0.675 & 1.038 \\
\hline & Covariance & 0.493 & 3.464 & -0.135 & 0.208 \\
\hline & $\mathrm{N}$ & 6 & 6 & 6 & 6 \\
\hline \multirow{5}{*}{ Urease } & PearsonCorrelation & $0.975(* *)$ & 1 & -0.287 & $0.990(* *)$ \\
\hline & Sig. (2-tailed) & 0.001 & & 0.581 & 0.000 \\
\hline & Sum of Squaresand Cross-products & 17.319 & 128.078 & -4.232 & 7.711 \\
\hline & Covariance & 3.464 & 25.616 & -.846 & 1.542 \\
\hline & $\mathrm{N}$ & 6 & 6 & 6 & 6 \\
\hline \multirow{5}{*}{ FRAP } & PearsonCorrelation & -0.330 & -0.287 & 1 & -0.380 \\
\hline & Sig. (2-tailed) & 0.523 & 0.581 & & 0.458 \\
\hline & Sum of Squaresand Cross-products & -0.675 & -4.232 & 1.698 & -0.341 \\
\hline & Covariance & -0.135 & -0.846 & 0.340 & -0.068 \\
\hline & $\mathrm{N}$ & 6 & 6 & 6 & 6 \\
\hline \multirow{5}{*}{ DPPH } & PearsonCorrelation & $0.961(* *)$ & $0.990(* *)$ & -0.380 & 1 \\
\hline & Sig. (2-tailed) & 0.002 & 0.000 & 0.458 & \\
\hline & Sum of Squaresand Cross-products & 1.038 & 7.711 & -0.341 & 0.474 \\
\hline & Covariance & 0.208 & 1.542 & -0.068 & 0.095 \\
\hline & $\mathrm{N}$ & 6 & 6 & 6 & 6 \\
\hline
\end{tabular}

\section{Discussion}

Many studies have reported the TPC as an indicator of biological activity (Djeridaneet al., 2006; Havsteen, 2002). Phenolic compounds are substances that have reducing properties, which make them antioxidant properties, such as hydrogen donors or singlet oxygen quenchers (Djeridane et al., 2006). Determined the total phenolic and flavonoid content, also used two other assays to quantify the antioxidant capacity of the extracts. These assays are widely used to determine the antioxidant activity test of natural products. The results from these assays are presented in Table 1. The extracts from both parts of the plant (leaves and roots) showed ferric reducing effects, which are related to the antioxidant capacity and the leaf was found to have higher FRAP values than the root. Similar to the FRAP results, we also observed DPPH radical scavenging activity in the extracts of both parts of the plant, and the leaves had a higher radical scavenging activity than the roots. Therefore, the extracts from the leaves of the plant had a higher TPC and higher antioxidant capacity than the roots. The roots store most of the carbohydrates of the plants, which may explain their reduced phenolic concentration. The lower TPC of the roots demonstrates lower inhibition of the enzymes (Baltas et al., 2016).

Silibinin (or silybin) is the main flavonoid of silymarin, a standardized extract of milk thistle (Silybum marianum) seeds. Silibinin A and silibinin B, which are both silymarin compounds, have been reported to be found in equimolar ratios in Silybum marianum (DavisSearles et al., 2005). Many researchers have reported that silibinin isomers have important biologically active properties, including protective effects on the liver (Abenavoli et al., 2010; Saller et al., 2008; Y1ldı et al., 2013) and prevention against prostate cancer (Davis-
Searles et al., 2005; Flaig et al., 2007). Ferulic acid has an important role in providing the rigidity of cell walls and in the formation of other important compounds, such as coniferyl alcohol, vanillin, diferulic acid and curcumin (Kumar and Pruthi, 2014). The results from our study suggest that $C$. benedictus is a good source of phenolic compounds, including silibinin, vanillin acid, ferulic acid and rutin. The regular consumption of the roots and leaves of this plant may have a protective effect against many diseases, particularly liver disease and cancer. This work also aimed to determine whether the plants exhibit an inhibitory effect on two enzymes which are of vital importance in human health. Common inhibitors of the enzymes could be significant to alternative medicine in the treatment of gastric ulcers and gout (Can and Baltas, 2016).The methanolic extracts were found to have different inhibition concentrations for these enzymes. The anti-XO activity of both the leaves and roots were similar, ranging between 18.53 and $19.75 \mathrm{mg} / \mathrm{mL}$. However, the inhibition of urease was better in the leaf extracts. When the inhibition concentrations were compared to the known standards for these enzymes, our findings were lower than that of the allopurinol and acetohydroxamic acid. The lower enzyme inhibition values compared to these pure enzyme inhibitors may be explained by the purity of the samples. Methanolic extracts were used in this study, and these extracts also contained some secondary metabolites, carbohydrates and lactoniclignins (Sólyomváry et al., 2014). The leaf and root extracts contained approximately $0.64 \%$ and $0.34 \%$ TPC (Table 1), respectively. There is limited information in the literature about TPC, TFC and the enzyme inhibition concentration for Cnicus benedicts, therefore, comparisons cannot be made. We observed moderate inhibition against both of these enzymes by both 
methanolic extracts. Results confirm that used as a food source can be founded both antioxidant activity and phenolic compounds the roots and leaves of Şevketi Bostan and it is also very rich in anti-inflammatory activities the roots and leaves of Şevketi Bostan. The consumable parts of Cnicus benedicts L. are rich in phenolic compounds, which is important as the production and consumption of this plant has increased. Furthermore, the high amount of both silibinin and vanillic acid enables its use in ethnopharmacology, phytotherapy and food chemistry. Also our results were show that when consumed together in both parts, of the C.benedicts L. it will be more beneficial for human health and it is also necessary to increase the cultural presentation of this plant.

\section{Acknowledgments}

Our research group would like to thank the EGE (Tarımsal Araştırma Enstitüsü) for supply cultivated Şevketi Bostan plants to be used in this study.

\section{Conflict of Interest}

The authors declare that they have no conflict of interests.

\section{References}

Abenavoli L, Capasso R, Milicn, Capasso F. 2010. Milk thistle in liver diseases: past, present, future. Phytotherapy Res., 24: 1423-1432.

Ahmed-Belkacem A, Ahnou N, Barbotte, L., Wychowski, C. Pallier, C., Brillet, R., Pohl, R. T.,Pawlotsky, J. M. (2010). Silibinin and related compounds are direct inhibitors of hepatitis $\mathrm{C}$ virus RNA-dependent RNA polymerase.Gastroenterology, 138: $1112-1122$.

Baltas N,Yildiz O,Kolayli S. 2016. Inhibition properties of propolis extracts to clinically important enzymes; acetylcholine esterase, urease and xanthine oxidase. J Enzyme Inhib Med Chem., DOI: 10.3109/14756366.2016.1167049.

BenzeieI FF, Strain JJ. 1996. The ferric reducing ability of plasma (FRAP) as a measure of "antioxidant power": The FRAP assay. Analy. Biochem., 239: 70-76.

Can Z, Yildiz O, Sahin H, Turumtay EA, Silici S, Kolayli S. 2015. An investigation of Turkish honeys: their physico-chemical properties, antioxidant capacities and phenolic profiles. Food Chem., 180: 133-141.

Can Z, Baltas N. 2016.Bioactivity and enzyme inhibition properties of Steviare baudiana. current enzy. Inhibit., 12(2):188-194.

Chen GL, Chen F, Xie YQ, Han MD, Luo CX, Zhao YY, Gao Y.Q. 2016. Nutraceutical potential and antioxidant benefits of selected fruit seeds subjected to an in vitro digestion. J Funct. Foods, 20: 317-331.

Chen R, Jina C, Tong Z, Lua J, Tana L, Tiana L, Chang Q. 2016. Optimization extraction, characterization and antioxidant activities of pectic polysaccharide from tangerine peels. Carbohydr. Polymers, 136: 187-197.

Davis-Searles PR, Nakanishi Y, Kim NC, Graf TN, Oberlies NH, Wani MC, Wall ME, Agarwal R, Kroll DJ. 2005. Milk thistle and prostate cancer: differential effects of pure flavonolignans from Silybum marianum on antiproliferative end points in human prostate carcinoma cells. Cancer Res., 65, 4448-4457.

Djeridane A, Yousfi M, Nadjemi B, Boutassouna D, Stocker P, Vidal N. 2006. Antioxidant activity of some Algerian medicinal plants extracts containing phenolic compounds. Food Chem., 97: 654-660.
EşiyokD, Otles S, Akcicek E. 2004. Herbs as a food source in Turkey. Asian Pacific J Cancer Prevent., 5: 334-339.

Flaig TW, Gustafson DL, Su LS, Zirrolli JA, Crighton F, Harrison GS, Pierson AS, Agarwal R, Glodé LM. 2007 A phase I and pharmacokinetic study of silybin-phytosome in prostate cancer patients. Investigational New Drugs, 25: 139-146. doi: 10.1007/s10637-006-9019-2.

Fukumoto LR, Mazza G. 2000. Assessing antioxidant and prooxidant activities of phenolic compounds. J Agric. Food Chem., 48: 3597-3604.

Havsteen BT. 2002. The biochemistry and medical significance of the flavonoids. Pharmacol. Therapeutics, 96: 67-202.

Hayashi T, Sawa K, Kawasaki M, Arisawa M, Shimizu M, Morita N. 1988. Inhibition of cows milk xanthine-oxidase by flavonoids. J Natural Prod., 51: 345-348.

Hermann KM. 1995. The Shikimate pathway: early steps in the biosynthesis of aromatic compounds. The Plant Cell, 7: 907919.

Kolayli S, Kara M, Tezcan F, Erim FB, Sahin S, Ulusoy E, Aliyazicioglu R. 2010. Comparative study of chemical and biochemical properties of different melon cultivars: standard, hybrid, and grafted melons. J Agric. Food Chem., 58: 97649769.

Kolayli S, Sahin H, Can Z, Yildiz O, Sahin K. 2015. Honey shows potent inhibitory activity against the bovine testes hyaluronidase. J Enzyme Inhib Med Chem., 31: 599-602. doi: $10.3109 / 14756366$.

Kumar N, Pruthi V. 2014. Potential appications of ferulic acid from natural sources. Biotechonology Reports, 4: 86-93.

Kuppusamya S, Thavamani P, Megharaj M, Naidu R. 2015. Bioremediation potential of natural polyphenol rich green wastes: a review of current research and recommendations for future directions. Enviro Technol.Innovat., 4: 17-28.

Liu S, Zhang J, Li D, Liu W, Luo X, Zhang R, LiL, Zhao J. 2007. Anticancer activity and quantitative analysis of flavone of Cirsium japonicum DC. Natural Prod. Res., 21: 915-922.

Lucini L, Kane D, PellizzoniM, Ferrari, A,Trevisi E, Ruzickova G, Arslan D. 2016. Phenolic profile and in vitro antioxidant power of different milk thistle [Silybum marianum (L.) Gaertn.] cultivars. Indust. Crops and Prod., 83: 11-16.

Martin RJ, Lauren DR, Smith WA, Jensen DJ, Deo B, Douglas JA. 2006.Factors influencing silymarin content and composition in variegated thistle (Silybum marianum). J CropHorticult. Scie., 34: 239-245.

Mehta SK, Nayeem N. 2014. Natural xanthine oxidase inhibitors for management of gout: a review. Research and Reviews: J Med. Health Scie., 3:1-13.

Molyneux P. 2004. The use of the stable free radical diphenylpicrylhyrazyl (DPPH) for estimating antioxidant activity. Songklanakarin J Scie. Technol., 26: 211-219.

Naczk M, Shahidi F. 2004. Extraction and analysis of phenolics in food. J Chromatography. A, 1054: 95-111.

Ndemangou B, Siellnou VT, Vardamides JC, AlI MS, Lateef M, Iqbal L, Afzan, Nkengfack, AE. 2013. Urease inhibitory isoflavonoids from different parts of Calopogoniummucunoides(Fabaceae). J Enzyme Inhib Med Chem., 28: 1156-1161.

Sahin H. 2015. Honey as an apitherapic product: its inhibitory effect on urease and xanthine oxidase.. J Enzyme Inhib Med Chem., 31: 490-494.

Salla S, Sunkara R, Ogutu S, Walker LT, Verghese M. 2016. Antioxidant activity of papaya seed extracts against $\mathrm{H}_{2} \mathrm{O}_{2}$ induced oxidative stress in HepG2 cells. LWT - Food Sci. Technol., 66: 293-297.

Saller R, Brignoli R, Melzer J, Meier R. 2008. An updated systematic review with meta-analysis for the clinical evidence of silymarin. Forschende Komplementarmedizin, 15: 9-20.

Shahidi F, Ambigaipalan P. 2015. Phenolics and polyphenolics in foods, beverages and spices: Antioxidant activity and health effects - A review. J. Funct. Foods, 18: 820-897. 
Slinkard K, Singleton VL. 1977. Total phenol analyses: automation and comparison with manual methods. American J. of Enol. Viticult., 28: 49-55.

Sólyomváry A, Tóth G, Kraszni M, Noszál B, Molnár-Perl I, Boldizsár I. 2014. Identification and quantification of lignans and sesquilignans in the fruits of Cnicus benedictus L.: quantitative chromatographic and spectroscopic approaches. Microchem. Journal, 114: 238-246.
Yildiz O, Can Z, Saral O, Yulug E, Ozturk F, Aliyazicioglu R, Canpolat S, Kolayli S. 2013. Hepatoprotective potential of chestnut bee pollen on carbon tetrachloride. Evidence-Based Comp. Altern. Med., 461478,9.

Weatherburn MW. 1967. Phenol-hypochlorite reaction for determination of ammonia. Anal. Chem, 39, 971-974. 